\title{
The Capability of Pronouncing French Phonemes by STUDENTS OF ENGLISH DEPARTMENT, UDAYANA UNIVERSITY
}

\author{
Ni Luh Ketut Mas Indrawati, A.A.Istri Aryani, Putu Weddha Savitri \\ English Department, Faculty of Arts, Udayana University \\ mas_indrawati@unud.ac.id, istri_aryani@unud.ac.id, weddha_savitri@unud.ac.id
}

\begin{abstract}
This study aims at investigating the ability of the pronunciation of French phonemes by students of English Department, Faculty of Culturale Studies, Udayana University. It also intends to analyse the way they articulated the phonemes and identified factors affecting their pronunctiation. This research is very interesting to do considering that the correct pronunciation of a phoneme or sound of a Foreign Language is one of the important points that must be mastered by the learners. The French sound system which is different from that of Indonesian and English certainly becomes one of the obstacles for students besides their lack of knowledge about the French phonemes. It is important to know which phonemes they have been able to pronounce and which are still difficult for them, so that inovations in teaching French can be made, especially in enhancing students' ability in pronouncing sounds which are considered difficult in French. Forty students of English Department who chose French as their elective subject were taken as the population of this study. The data were taken by applying observation method using questionnaires, recording, and note taking techniqes. The data were descriptive-qualitatively analysed by applying the theory of phonology.
\end{abstract}

Keywords: capability, pronunciation, phonemes, French

\section{INTRODUCTION}

The ability to communicate in foreign languages is very important in the digital era and globalization since this can facilitate communications and interactions of modern people in the world. Language difference is one of the obstacles to communicate effectively in international communication; therefore, nowadays people are competing in mastering foreign languages for various reasons or needs, such as economy, job, cultural exchange, travel, and even to increase the self-prestige in the society.

English as an international language is the first foreign language that must be mastered to be able to communicate with people from other nations. But now, having other foreign language skills would be better to be able to further the insight and self-esteem in the job competition in the world. Therefore, English Department, Faculty of Culturale Studies, Udayana University offers Elective Courses on foreign languages, one of which is French. French can be regarded as one of the international languages because it is used by more than 200 million people in different parts of the world. This course is given early for 2 semesters ( 2 credits/semester) and most students have never had French before so it is not easy for them to understand and master it in such a short time.

There are several aspects and skills that must be learned by students in French Language Courses, such as the ability to read, write, listen and speak. In the context of the ability to speak, students are taught about the sound system in French. Pronunciation is one of the most difficult things for students because French sound system is much different that of from Indonesian and English. Sound system is something that is universal, but each language has its own uniqueness that distinguishes it from other languages. When studying a foreign language, the sound system possessed by the language becomes one of the most important points that must be mastered to speak the language well and correctly. The ability to pronounce words correctly is a person's ability to understand sound system of which impact is on the accuracy of meaning. In the context of French, the correct pronunciation of sounds composed in the word will greatly affect the comprehension of the listener, because the difference in sound can cause different meaning.

On the other hand, language skills do not only involve writing, reading, and listening but also speaking. A relative short time and a large number of students seem to be the obstacles in mastering the French sound system well, especially in the pronunciation of vowels, consonants, diphthongs, stressing, etc. However, good pronunciation will support speaker's performance, and conversely inappropriate pronunciation will be a benchmark that a person is not able to learn the language entirely, it is the indicator that there must be a solution to minimise problems.

In this research there were three problems that could be raised, they were: 1) how was the student's ability in pronuncing French phonemes, 2) How were the realizations of sounds produced by students, and 3) What factors might affect the student's ability in mastering phonemes in French? 


\section{MATERIALS AND METHOD}

This study was classified as a field research and the population was 40 students taking French in the English Department, Faculty of Culturale Studies, Udayana University. The data were collected by distributing topics to the students and asked them to speak and while speaking the recording was done. Recording is also done by asking students to say a particular vocabulary containing all the phonemes in French.

The data on the factors affecting the students' abalities were collected by distributing questionnaires to the students. The data were then classified based on the problems raised. The data were analysed in a descriptive qualitative way based on the theory of phonology.

\section{RESULTS AND DISCUSSION}

\subsection{PhONOLOGY}

Phonology is the study of sound system in a language. Collins and Mees (2003: 1) state that the study of the selection and patterns of sounds in a single language is reffered to as phonology. They mention that in getting a full idea of the way the sounds of a language work, it is required to study not only the phonetics of the language concerned but also its phonological system. Both phonetics and phonology are important components of linguistics which is the science that deals with the general study of language. They also claim that the study of both phonetics (the science of speech sound) and phonology (how sounds combine and function in a given language) will assist learners to learn more about a language.

Kelly (2000: 9) claims that the study of pronunciation consists of two fields, they are phonetics and phonology. Phonetics refers to the study of speech sounds, it is a wide-ranging field, while phonology is primarily concerned with how we interpret and systematize sounds so it deals with the system and pattern of the sounds which exist within particular languages. Kelly (2000: 1) also shows the features of pronunciation which cover phonemes consisting of consonants and vowels, and suprasegmental features including intonation and stress. She states that the different sounds within a language are referred to as phonemes. When considering meaning, we notice how using one sound rather than another can change the meaning of the word. This is the principle in identifying the number of phonemes in a particular language.

\subsection{Phonemes in French}

Phoneme is defined as the smallest unit of sound which can contrast the meanings of two words, for example in English /f/ and /v/ are of different phonemes this can be shown by the minimal pairs: ferry /feri/ and very /veri/, the two words are only different in one sound that is; /f/ and /v/ then they have different meanings. In linguistics phoneme symbols are written in between slanting lines: /.../.

According to Valsman (1993) French has 37 phonems that is; 18 consonants and 19 vowels, this can be illustrated using phonemic symbols as follows;

Table 1. Consonant phonemes in Standard French

\begin{tabular}{|c|c|c|c|c|c|c|}
\hline & & Labial & $\begin{array}{l}\text { Dental/ } \\
\text { Alveolar }\end{array}$ & Palatal & Velar & Uvular \\
\hline Nasal & & $\underline{\mathrm{m}}$ & $\underline{\mathrm{n}}$ & $\mathrm{n}$ & (n) & \\
\hline & voiceless & $\mathrm{p}$ & $\underline{\mathrm{t}}$ & & $\underline{\mathrm{k}}$ & \\
\hline & voiced & $\underline{\mathrm{b}}$ & $\underline{\mathrm{d}}$ & & $\mathrm{g}$ & \\
\hline & voiceless & $\underline{f}$ & $\underline{\mathrm{s}}$ & $\int$ & $(\underline{\mathrm{x}})$ & \\
\hline & voiced & $\underline{\mathrm{v}}$ & $\underline{\mathrm{Z}}$ & 3 & & \\
\hline Approximant & Plain & & 1 & $\mathrm{i}$ & & \\
\hline
\end{tabular}




\begin{tabular}{|l|l|l|l|l|l|}
\hline & rounded & & $\underline{\underline{w}}$ & $\underline{\mathrm{w}}$ & \\
\hline
\end{tabular}

$/ \mathbf{p} /$ - plage, public

/b/ - bon, bêtise, ㅁateau

/t/ - terre, sottise, thé

/d/ - dîner, dimanche

$/ \mathbf{k} /$ - cou, carreau, que

/g/ - gare, gants, gallois

/f/ - flic, pharmacie, fossé

/v/ - vous, avion

/l/ - le, lait, mille

/s/ - sac, soixante, cerise

$\mid \mathbf{z} /$ - zoo, visage, guise

/ $/$ / chat, chinois, short

/3/ - japonais, je, génial

$/ \mathbf{m} /$ - mêler, magasin

$/ \mathbf{n} /$ - nous, $\underline{\text { nez }}$

$/ \mathbf{p} /$ - agneau, poignet (found in French only)

/y/ - camping, smoking (americanized phoneme)

$/ \mathbf{R} /$ - rue, rouge (modified in French)

French has 13 oral vowels, 4 nasalised vowels, and 3 semivowels as shown in the following table

Table 2. Vowel phonemes in Standard French

\begin{tabular}{|c|c|c|c|c|c|}
\hline & \multicolumn{2}{|l|}{ Front } & \multirow{2}{*}{ Central } & \multirow{2}{*}{ Back } \\
\hline & & unrounded & Rounded & & \\
\hline$\underline{\text { Close }}$ & \multirow{3}{*}{ oral } & $\underline{\mathrm{i}}$ & y & & $\underline{\mathrm{u}}$ \\
\hline Close-mid & & $\underline{\mathrm{e}}$ & $\underline{\emptyset}$ & \multirow{2}{*}{$\underline{\partial}$} & $\underline{\mathrm{o}}$ \\
\hline \multirow{2}{*}{ Open-mid } & & $\underline{\varepsilon}(\varepsilon:)$ & $\underline{œ}$ & & $\underline{0}$ \\
\hline & \multirow{2}{*}{$\underline{\text { nasal }}$} & $\tilde{\varepsilon}$ & $(\tilde{œ})$ & & $\tilde{\jmath}$ \\
\hline \multirow{2}{*}{ Open } & & & & & $\tilde{\mathrm{a}}$ \\
\hline & oral & & & $\underline{\mathrm{a}}$ & (a) \\
\hline & & & & & \\
\hline
\end{tabular}

Table 3. Example words

\begin{tabular}{|c|c|c|c|}
\hline Vowel & Exa & & \\
\hline \multicolumn{2}{|l|}{$\underline{\text { IPA }}$} & Orthography & Gloss \\
\hline \multicolumn{4}{|c|}{ Oral vowels } \\
\hline /i/ & /si/ & $\underline{s i}$ & 'if' \\
\hline /e/ & /fe/ & fée & 'fairy' \\
\hline $\mid \varepsilon /$ & $/ \mathrm{f} \varepsilon /$ & fait & 'does' \\
\hline
\end{tabular}




\begin{tabular}{|c|c|c|c|}
\hline $\mid \varepsilon: /$ & $/ f \varepsilon: t /$ & fête & 'party' \\
\hline$/ \partial /$ & $/ \mathrm{s} 2 /$ & $\underline{c e}$ & 'this'/'that' \\
\hline /œ/ & / сюь/ & $\underline{\text { seeur }}$ & 'sister' \\
\hline$|\varnothing|$ & $/ \mathrm{s} \varnothing /$ & ceux & 'those' \\
\hline$/ \mathrm{y} /$ & /sy/ & $\underline{s u}$ & 'known' \\
\hline$/ \mathrm{u} /$ & $/ \mathrm{su} /$ & $\underline{\text { sous }}$ & 'under' \\
\hline /o/ & $/ \mathrm{so} /$ & sot & 'silly' \\
\hline$/ \mathrm{s} /$ & /sob/ & sort & 'fate' \\
\hline$/ \mathrm{a} /$ & $/ \mathrm{sa} /$ & $\underline{s a}$ & 'his'/'her', \\
\hline$/ \mathrm{a} /$ & /pat/ & pâte & 'dough' \\
\hline \multicolumn{4}{|c|}{ Nasal vowels } \\
\hline$/ \tilde{\mathbf{a}} /$ & $/ \mathrm{s} \tilde{a} /$ & $\underline{\text { sans }}$ & 'without' \\
\hline$/ \tilde{\partial} /$ & /s̃̃/ & son & 'his' \\
\hline / $\tilde{\mathfrak{e}} /$ & /ьью̃ / & brun & 'brown' \\
\hline $\mid \tilde{\varepsilon} /[20]$ & /bьг̃ / & $\underline{\text { brin }}$ & 'sprig' \\
\hline \multicolumn{4}{|c|}{$\underline{\text { Semi-vowels }}$} \\
\hline$/ \mathrm{j} /$ & /јєв/ & $\underline{\text { hier }}$ & 'yesterday' \\
\hline$/ \mathrm{\psi} /$ & /plui// & pluie & 'rain' \\
\hline$/ \mathrm{w} /$ & /wi/ & $\underline{\text { oui }}$ & 'yes' \\
\hline
\end{tabular}

Vowels are speech sounds which are produced without any obstructions. For beginners it is hard for them to distinguish phonemes /y/vs /u/ and phonemes /œ/ vs /ø/. Symbol $(\sim)$ is assigned above the vowels for nasalized vowels while semivowels are produced by moving up the tongue quickly.

\subsection{THE ABILITY OF PRONUNCING FRENCH PHONEMES BY STUDENTS}

This section described the phonemes that have been and have not been mastered by the students and presented how they realize the sounds. There are 37 phonems in French, they are; 18 consonants and 19 vowels. Consonant phonemes are classified into Voiceless Consonants ( 6 phonemes) and Voiced Consonans (12 phonemes), meanwhile vowel phonemes are classified into Oral Vowels (12 phonemes), Nasal Vowels (4 phonemes), dan Semi Vowels (3 phonemes).

Based on the data obtained through direct observation or audio recording, it was found that some students had been able to produce some phonemes well, but some still have problems in pronouncing certain phonemes. This can be illustrated in the following table: 
Table 4. Voiceless Consonants

\begin{tabular}{|l|l|l|l|}
\hline phonemes & Example words & $\begin{array}{l}\text { Number of students making } \\
\text { mistakes }\end{array}$ & Percentage \\
\hline$/ \mathrm{p} /$ & Pou /pu/ & - & $0 \%$ \\
\hline$/ \mathrm{t} / \mathrm{f}$ & Tout /tu/ & - & $0 \quad \%$ \\
\hline$/ \mathrm{k} /$ & Cou /ku/ & - & $0 \quad \%$ \\
\hline$/ \mathrm{f} /$ & Fou /fu/ & 2 & $5 \quad \%$ \\
\hline$/ \mathrm{s} /$ & Sous /su/ & - & $0 \%$ \\
\hline$/ \mathrm{f} /$ & Chou /fu/ & 5 & $12,5 \%$ \\
\hline
\end{tabular}

Table 5. Voiceless Consonants

\begin{tabular}{|l|l|l|l|}
\hline phonemes & Example words & $\begin{array}{l}\text { Number of students making } \\
\text { mistakes }\end{array}$ & Percentage \\
\hline$/ \mathrm{p} /$ & Pou /pu/ & - & $0 \%$ \\
\hline$/ \mathrm{t} /$ & Tout /tu/ & - & $0 \%$ \\
\hline$/ \mathrm{k} /$ & Cou /ku/ & - & $0 \%$ \\
\hline$/ \mathrm{f} /$ & Fou /fu/ & 2 & $5 \%$ \\
\hline$/ \mathrm{s} /$ & Sous /su/ & - & $0 \%$ \\
\hline$/ \mathrm{g} /$ & Chou /Ju/ & 5 & $12,5 \%$ \\
\hline
\end{tabular}

The table above shows that students mostly have problems in pronouncing voiceless consonants, the error occurs mostly in the pronunciation of phoneme $/ \mathrm{f} /$ that is 5 students, and only 2 students made mistakes in pronouncing /f/ that is 2 students. What happens to the pronunciation of phoneme $/ \int /$ is that most students produced this phoneme like phoneme $/ \mathrm{s} /, / \int /$ should be pronounced in the palatal position, not dental/alveolar. While the error in the phoneme / f / which is a voiceless labio-dental fricative consonant can be said to be small because only one student pronounced this phoneme with the sound / v / which is a voiced labio-dental fricative consonant. While other consonants included in this group such as $/ \mathrm{p} /, / \mathrm{t} /, / \mathrm{k} /$, and $/ \mathrm{s} / \mathrm{can}$ be pronounced easily by students. This is due to the existance of these phonemes in the mother tongue of the students.

Table 6. Voiced consonants

\begin{tabular}{|l|l|l|l|}
\hline phonemes & Example words & $\begin{array}{l}\text { Number of students } \\
\text { making mistakes }\end{array}$ & Percentage \\
\hline$/ \mathrm{b} /$ & Boue /b/ & - & $0 \%$ \\
\hline$/ \mathrm{d} /$ & Doux /d/ & - & $0 \%$ \\
\hline$/ \mathrm{g} /$ & Gout /g/ & - & $0 \%$ \\
\hline$/ \mathrm{v} /$ & Vous /v/ & 10 & $25 \%$ \\
\hline$/ \mathrm{z} /$ & Zoo /z/ & 4 & $10 \%$ \\
\hline$/ 3 /$ & Joue /3/ & 14 & $35 \%$ \\
\hline
\end{tabular}




\begin{tabular}{|l|l|l|l|}
\hline$/ \mathrm{n} /$ & Nous /nu/ & - & $0 \%$ \\
\hline$/ \mathrm{m} /$ & Mou /mu/ & - & $0 \%$ \\
\hline$/ \mathrm{l} / \mathrm{L}$ & Loup /lu/ & $0 \%$ \\
\hline$/ \mathrm{n} /$ & Champagne /Jampan/ & 8 & $20 \%$ \\
\hline$/ \mathrm{y} /$ & Camping /kampin/ & - & $0 \%$ \\
\hline$/ \mathrm{R} /$ & Roue /вu/ & 19 & $47,5 \%$ \\
\hline
\end{tabular}

The ability of students in pronouncing this voiced consonant group can be seen in the above table. The phoneme / $\mathrm{R} /$ becomes the most difficult phoneme because it has a in compared to phoneme / $\mathrm{r} / \mathrm{in}$ Indonesian. Both phonemes are equally voiced consonants that are sounds that occur with the vibration of the active articulation region. But they are different in the way of voicing. Phoneme / $\mathrm{R} /$ is a vibration of the throbbing (vibration of the tongue behind and the throb) while the phoneme / $\mathrm{r} /$ Indonesian is the vibration of the front tongue and the ceiling. Because of this similarity, as many as 19 students are not yet accustomed to producing sounds / R / which exists in French sound system, and it was articulated like phoneme / $\mathrm{r} / \mathrm{in}$ Indonesian.

The other phoneme which is also quite difficult for the students is phoneme / 3 / errors in the pronunciation of this phoneme were done by 14 students. / 3/ is a voiced consonant, it is realized by forcing air out through a narrow channel formed by pressing together the blade of the tongue and the hard palate. The production of phoneme / 3 / is very close to that of phoneme / $\mathrm{z}$ / because they both are equally voiced and belong to fricative consonants, however in terms of place of articulator they are different, / 3 / belongs to palatal consonant. / $\mathrm{z}$ / is a voiced alveolar fricative consonant, only 4 students had problems in pronouncing it. This is due to the occurance of this phoneme in their mother tongue, however in Indonesian [z] and [s] are often used as variants of phoneme /z/. This influenced the pronunciation of $/ z /$ in French.

Phoneme / v / was also problems for 10 students, based on direct and indirect observation, these students produce it like / $\mathrm{f} /$. This is because both of these phonemes are both labiodental fricative consonants (consonants produced by bringing the upper teeth and lower lip), but they are different in voicing in that $/ \mathrm{v} /$ is voiced while $/ \mathrm{f} /$ is voiceless.

Phoneme / $\mathrm{n} /$ is produced with an articulated nasal by using the center of the tongue with a soft palate. In Indonesian sound system, it is somewhat similar to phoneme [ny] but they are different in quality. In this case, 8 students made mistakes because they produced it like phoneme /ny/ in Indonesian.

Based on the above analysis it could be stated that students still had problems in pronouncing French consonants. They most had problems in producing phoneme / $\mathrm{R} /$, and 5 other phonemes that is; / $\mathrm{v} / \mathrm{l} / \mathrm{z} /$, and $/ \mathrm{n} /$.

Table 7. Oral Vowels

\begin{tabular}{|c|c|c|c|}
\hline phonemes & Example words & $\begin{array}{l}\text { Number of students } \\
\text { making mistakes }\end{array}$ & Percentage \\
\hline /i/ & $\mathrm{Si} \quad / \mathrm{si} /$ & - & $0 \%$ \\
\hline /e/ & Fée $\quad / \mathrm{fe} /$ & 5 & $12,5 \%$ \\
\hline$/ \varepsilon /$ & Fait $/ f \varepsilon /$ & 16 & $40 \%$ \\
\hline$/ \mathrm{a} /$ & $\mathrm{Ce} \quad / \mathrm{s} \partial /$ & 14 & $35 \%$ \\
\hline$/ œ /$ & Sœur /sœr/ & 32 & $80 \%$ \\
\hline $\mid \varnothing /$ & Ceux $\quad / s ø /$ & 30 & $75 \%$ \\
\hline$/ \mathrm{y} /$ & $\begin{array}{ll}\mathrm{Su} & / \mathrm{sy} /\end{array}$ & 28 & $70 \%$ \\
\hline
\end{tabular}




\begin{tabular}{|c|c|c|c|}
\hline$/ \mathrm{u} /$ & Sous /su/ & - & $0 \%$ \\
\hline$/ \mathrm{o} /$ & Sot $/ \mathrm{so} /$ & 10 & $25 \%$ \\
\hline$/ \mathrm{s} /$ & Sort /soR/ & 14 & $35 \%$ \\
\hline$/ \mathrm{a} /$ & $/ \mathrm{sa} /$ & 6 & $15 \%$ \\
\hline$/ \mathrm{a} /$ & Pate /pat/ & 8 & $20 \%$ \\
\hline
\end{tabular}

The table above shows that students had problems in pronouncing, it can be seen that for the pronunciation or production of oral vowels, students encountered difficulties in producing almost all phonemes in this group. Vowel is distinguished in terms of tongue position, parts of the tongue involved, and shape of the lips when pronouncing it. For this oral vowel group, only two phonemes could be well pronounced by the student ie phoneme / i / and / u / whereas the other phonemes have a certain degree of difficulty so that many of the students make mistakes in producing them.

- Phoneme $/ \mathrm{e} /, / \varepsilon /$, and $/ \mathrm{\jmath} /$ are also quite difficult to be pronounced because their differences are determined by the position of the tongue while the lip formed an unrounded shape for all those phonemes. Phoneme /e/ is produced by raising the front tongue $2 / 3$ higher than open vowel (semi-closed), phoneme $\mid \varepsilon /$ is produced with the position of front tongue raised $1 / 3$ higher than open vowel (semi-open), and phoneme $/ a /$ produced by raising the mid tongue $1 / 3$ below closed vowel. The same case with previous explanation, the students have not been able to place their tongue in the right position so that the sound produced was not clear enough to show the difference. The most sound heard is [e] because this sound is frequently and easily pronounced by Indonesian students.

- Vowel phonemes with high difficulty level are phoneme / œ /, / ø/, and / y /. These phonemes are equally articulated by forming the lips round, but the structure or state of positional relationships between the tongue and the ceiling is different. Sounds [œ] are the most difficult vocal sounds for students to produce where as many as 32 people could not pronounce it correctly, followed by the sounds [ø] and [y].

- In terms of the shape of the lips, the phonem / $\propto$ / is produced by the position of the tongue raised in the height of two-thirds below the closed vocals or one third above the open (semi-open) vocals, phoneme / $\varnothing$ / generated by the position of the raised tongue two-thirds above the open vocal (semi closed), while the phoneme / y / is produced by lifting the tongue as high as possible close to the ceiling (closed vowels). Because the position of the tongue is only slightly different for each of these phonemes then the students have difficulty in placing the tongue in accordance with its position so that for these three phonemes it is very difficult for students to produce. Students inclined to produce them in a similar way so it is not clear which phonemes they produced.

- Phoneme / o / and / o / can be considered to have a low degree of difficulty due to the equally rounded lip position but part of the tongue involved is different that is; /o/ is produced by involving the middle tongue, while / $/$ / by involving the back of the tongue. Students have problem in producing them due to lack of knowledge of which words containing phoneme [o] and vice versa.

- Phonemes / a / and / a / are not too difficult to pronounce with the number of students making mistakes in pronunciation of these two phonemes are low. Both belong to open vowels however; they are different in terms of part of the tongue involved in producing them. /a/ is produced by involving middle part of the tongue while /a/ by moving the back part of the tongue.

Table 8. Nasal vowels

\begin{tabular}{|c|c|c|c|}
\hline phonemes & Example words & $\begin{array}{l}\text { Number of students making } \\
\text { mistakes }\end{array}$ & Percentage \\
\hline$/ \tilde{\mathrm{a}} /$ & Sans $\quad /$ sã $/$ & 8 & $20 \%$ \\
\hline$/ \tilde{\mathbf{z}} /$ & Son $/$ s̃̃ $/$ & 8 & $20 \%$ \\
\hline$/ \tilde{\mathfrak{e}} /$ & Lundi /lõ̃di/ & 24 & $60 \%$ \\
\hline $\mid \tilde{\varepsilon} /$ & 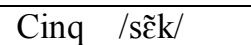 & 10 & $25 \%$ \\
\hline
\end{tabular}

The above table shows that the students' ability in pronouncing nasal vowel phonemes indicates that these phonemes are difficult for them, since nearly $60 \%$ of students had problems in pronouncing 
these phonemes correctly. While the other nasal phonemes, / $\tilde{a} /, / \tilde{\partial} /, / \tilde{\varepsilon} /$, could be quite well articulated (it was only only about $20 \%-25 \%$ of students were still unable to produce them well) The nasal sounds that accompany nasal vowels are not really a problem in the realization, but what was still difficult to be articulated was the sound [œ] itself.The same is true of other nasal vocal phonemes, that is, students have not yet mastered the pronunciation of phonemes; [a], [o], [œ], and [a ] correctly.

\section{Semi Vowels}

\begin{tabular}{|l|l|l|l|}
\hline Fonem & Example words & $\begin{array}{l}\text { The numbers of students making } \\
\text { mistakes in pronouncing) }\end{array}$ & Percentage \\
\hline /j/ & Fille /fij/ & 18 & $45 \%$ \\
\hline$/ \mathrm{q} /$ & Nuit /nui/ & 10 & $25 \%$ \\
\hline$/ \mathrm{w} /$ & oui /wi/ & - & $0 \%$ \\
\hline
\end{tabular}

Semi vowels are sounds that have both vocal and consonant features, the slight shift and do not form the syllable core, for example in French [j] in accordance with [i]; [w] for [u]; [u] for [y] (https://kbbi.web.id/semivokal). Semivowel qualities are determined not only by the place of articulation but also by the shape of the mouth involved in producing them. For the group of semivowel sounds, students still make articulation errors on the phoneme / $\mathrm{j} /$ and / $\mathrm{u} /$, while phoneme / $\mathrm{w} /$, had been mastered by all students. The sounds produced by the students for each semivowel phoneme are as follows:

- phoneme / $\mathrm{j}$ / was often articulated as sound [i]. Sound [i] is the highest sound in the vowel group, The sound resulting from the structure of the mouth like this is the phoneme $/ \mathrm{j} /$.

- phoneme / $\mathrm{y}$ / was also articulated like / $\mathrm{u}$ /. Phoneme / $\mathrm{y}$ / is produced by involving the middle of the tongue with a round-mouth shape.

- phoneme / w / was also said to be semi-vowels because it is produced by round lips and it is bilabial vowel. For this phoneme, students could pronounce it correctly and had no difficulty in articulating it.

Based on the above analysis, the students' ability in pronuncing French phonemes could be considered low because out of 37 existing phonemes, 24 phonemes are still problems for them. But the students' ability for each phoneme varied, there were some phonemes of which error rate is very high are phonemes / $\mathrm{R} /, / \varnothing /, / \propto /, / \mathrm{y} /$, and / œ /, where almost $65 \%$ of the population can not pronounce it correctly. As for phonemes / v /, / $\mathrm{n} /, / \varepsilon /, / \mathrm{\rho} /, / \mathrm{o} /, / \mathrm{\rho} /, / \mathrm{a} /, / \mathrm{a} /, / \mathrm{\rho} /, / \mathrm{j} /$ and $/ \mathrm{u} /$ at a moderate level with $35 \%$ of the student population making mistakes in pronunciation.

Phonemes with very low pronunciation rates are phoneme / f /, / z /, / ع /, / e / and / a / which was only $12 \%$ of the student population were still less than perfect in pronuncing them. There are also phonemes that were highly controlled by the pronunciation of the students ie.; phoneme / p /, / t/, / k /, / $\mathrm{s} /, / \mathrm{b} /, / \mathrm{d} /, / \mathrm{g} /, / \mathrm{n} /, / \mathrm{m} /, / \mathrm{l} / \mathrm{l} / \mathrm{i} / \mathrm{l} / \mathrm{u} /$, and / w/.

\subsection{FACTORS AFFECTING THE MASTERY OF FRENCH PHONEME PRONUNCIATION}

In the pronunciation of French phonemes, students still made repeated mistakes both in the same phoneme as well as in other phonemes. For this reason, it is important to search for the causes that affect the students in mastering the pronunciation of these phonemes. Based on the results of questionnaires and interviews, here are some factors that affected students in mastering the pronunciation of French phonemes:

a. Some French phonemes do not exist in the students' mother tongue, in this case Indonesian and Balinese, nor in the foreign language that has been studied ie; English. This of course caused difficulties for students because they did not get used to producing the sounds. They also found it difficult to find the equivalent sounds therefore most of them replaced the phonemes by the closest sounds they were familiar with, such as phoneme / 3 / will be pronounced like / z/, phoneme / $\mathrm{s} /$ pronounced as / $\mathrm{r} /$, and others.

b. According to the students pronunciation of phonemes in French is quite difficult. They had never been heard or articulated these phonemes in conversations, such as phoneme $/ ø /, / \propto /, / \mathrm{J} /, / \mathrm{J} /, / \mathrm{a} /, / \mathrm{o} /, / \mathrm{u} /$, and others. They did not understand well how to articulate the phonemes correctly.

c. Lack of exercising. In order to produce the correct sound, it is necessary to practice frequently and repeatedly in pronunciation of French words. Besides speaking exercises, students also needed to listen to more audio such as video conversations, songs, movies, and others that could help them hear and then imitated what was heard and articulated. 
By acknowledging the French phonemic pronunciation ability of the students of English Department and the factors that influenced it, it would be easier for the teacher to be more focused or more intense in giving the knowledge or skill in articulating the French phonemes properly and correctly especially on the phonemes that were hard to pronounce.

\section{CONCLUSION}

Based on the analysis that had been done, it could be concluded that the students' ability in pronuncing French phoneme were still incorrect because there were still some phonemes which could not be well articulated. follows:

Phonemes that had been and had not been mastered by students of English Department are as

The phonemes that had been mastered by the students were: phonemes; / p /, / t/, / k /, / s /, / b /, / d /, / g /, / $\mathrm{n} /, / \mathrm{m} /, / 1 /, / \mathrm{i} /, / \mathrm{u} /$, and / w /, where $100 \%$ of students could pronounce them well.

Phonemes / $\mathrm{R} /, / \varnothing /, / \propto /, / \mathrm{y} /$, and $/ \propto /$ were phonemes with a very high pronunciation error rate that were $60 \%$ of students made mistakes in pronuncing these phonemes.

Phonemes / v /, / $\mathrm{g} /, / \varepsilon /, / \mathrm{a} /, / \mathrm{a} /, / \mathrm{o} /, / \mathrm{j} /$ and $/ \mathrm{y} /$ were the phonemes with the rate of error $35 \%$ of the populations.

Phonemes / f /, / z /, / ع /, / e / and / a / were phonemes with a low difficulty level because only $12 \%$ of students were not perfect in pronuncing them.

While the factor that influenced the mastery of French phoneme pronunciation by students was that because some French phonemes did not exist in their mother tongue that is Indonesian or the local language sound systems. The articulations of those phonemes were hard and the lack of audio pronunciation and listening exercises in which they could practise articulating the phonemes well.

\section{REFERENCES}

Collins, Baverley, and Inger M. Mees.2003. Practical Phonetics and Phonology. New York: Routledge

Helen Fraser, Teaching Pronunciation: A Handbook for Teachers and Trainers. New South Wales:

Department of Education Training and Youth Affairs DETYA, 2001.

Kelly, Gerald. 2000. How to Teach Pronunciation. England: Pearson Education Limited.

Mahsun. 2007. Metode Penelitian Bahasa (Edisi Revisi). Jakarta: PT. Rajagrafindo Persada

Masduki. 2004. "Studi Kemampuan Berbahasa Inggris Mahasiswa Non-English Department" Melalui Kegiatan Intensive Course Model B'

Thomas, Jacqueline M.C. 1976. Initiation à La Phonétique. Presse L’Universitaire de France

Valdman, A. (1993). Bien Entendu! Introduction à la prononciation française. Upper Saddle River, NJ: Prentice Hall.

http://kbbi.web.id/fonem 